\title{
Science Teacher Learning of MBL-Supported Student-Centered Science Education in the Context of Secondary Education in Tanzania
}

\author{
Joke Voogt $\cdot$ Frank Tilya $\cdot$ Jan van den Akker
}

Received: 12 October 2008/Accepted: 3 March 2009/Published online: 17 March 2009

(c) The Author(s) 2009. This article is published with open access at Springerlink.com

\begin{abstract}
Science teachers from secondary schools in Tanzania were offered an in-service arrangement to prepare them for the integration of technology in a studentcentered approach to science teaching. The in-service arrangement consisted of workshops in which educative curriculum materials were used to prepare teachers for student-centered education and for the use and application of Microcomputer Based Laboratories (MBL)—a specific technology application for facilitating experiments in science education. Quantitative and qualitative data were collected to study whether the in-service arrangement impacted teacher learning. Teacher learning was determined by three indicators: (1) the ability to conduct MBLsupported student centered science lessons, (2) teachers' reflection on those lessons and (3) students' perceptions of the classroom environment. The results of the research indicate that the teachers' were able to integrate MBL in their science lessons at an acceptable level and that they were able to create a classroom environment which was appreciated by their students as more investigative and open-ended.
\end{abstract}

Keywords Secondary education - Classroom practice . Student perceptions - ICT - Science education · Teacher learning

J. Voogt $(\bowtie) \cdot$ J. van den Akker

University of Twente, Enschede, The Netherlands

e-mail: j.m.voogt@utwente.nl

F. Tilya

University of Dar es Salaam, Dar es Salaam, Tanzania

\section{Introduction}

It is well known that sound integration of technology assumes that teachers need to learn: they need to learn the potential of technology for their subject, need to change their routines and learn to apply new pedagogical approaches (e.g. Sandholtz et al. 1997; Voogt 2003). Mishra and Koehler (2006) and Koehler and Mishra (2008) developed the Technological Pedagogical Content Knowledge Framework that allowed us to better understand the components that need to be incorporated in a learning trajectory for teachers, who want to integrate technology in their classroom practice, and the need for blending these components in particular. According to several scholars (e.g. McCrory 2008; Webb 2008) technology has transformed and expanded science research and for that reason also changed science education (what Mishra and Koehler call Technological Content Knowledge). McCrory (2008) mentions four elements critical for TPCK in the science domain: knowledge of science, knowledge of students' preconceptions, knowledge of science-specific pedagogy and knowledge of technology. This implies that a teacher needs to know which parts of the science curriculum are found difficult by his (her) students, and for which of these parts technology could be utilized in helping to solve the problem. In addition teachers need to know for which science topics technology is an essential part. Several scholars (e.g. Dede 2000) argue that student-centered approaches are appropriate in order to realize the potential of technology in the classroom. In addition developments in the learning sciences (see, for example, Bransford et al. 2000) show the benefits of student-centered forms of instruction for student learning. Strategies that align with studentcentered forms of instruction are learning by inquiry (e.g. Lumpe and Oliver 1991; Laws 1997); collaborative 
learning (e.g. Dillenbourg 1999) and formative assessment (e.g. Black and Wiliam 1998).

While the TPCK framework provides insight in what teachers need to learn when they want to integrate technology in science education, research about teacher professional development gives guidelines on how teacher learning might best be organized. Elmore and Burney (1999) describe successful teacher learning as: focusing on concrete classroom applications of general ideas; exposing teachers to actual practice rather than descriptions; providing opportunities for group support and collaboration and involving deliberate evaluation and feedback by skilled practitioners. Borko and Putnam (1996) suggest five features of professional development arrangements that facilitate the learning of practicing teachers. They are (a) addressing teachers' preexisting knowledge and beliefs about teaching, learning, learners, and subject matter; (b) enhancing teachers' subject matter and pedagogical content knowledge; (c) treating teachers as learners with an eye on principles of adult learning; (d) grounding teacher learning and reflection in classroom practice; and (e) offering ample time and support for reflection, collaboration, and continued learning. The first two features of professional development that Borko and Putnam mentioned are well aligned with the TPCK framework introduced by Koehler and Mishra (2008); the other three fit with the recommendations of Elmore and Burney (1999). Teacher professional development in this study is focused on preparing teachers to implement technology in their educational practice. Educative or exemplary curriculum materials (e.g. Van den Akker 1988; Ball and Cohen 1996; Davis and Krajcik 2005) not only provide learning materials for the student, these materials explicitly take the teacher as a learner into account. Educative curriculum materials help teachers in getting a clear picture of the goal of their learning, provide them with the necessary background information and support them while practicing what they learned in the classroom. Ottevanger (2001) has shown that educative curriculum materials embedded in teacher in-service can prepare teachers for the implementation of curriculum innovations. In addition several scholars (Ball and Cohen 1996; Borghi et al. 2003) promote the involvement of teachers in developing own curriculum materials to facilitate the enactment of curriculum innovations, such as the use of technology and a student-centered approach to education.

\section{Context}

This study took place in Tanzania, where the Ministry of Education and Vocational Education took a number of initiatives to realize the implementation of technology in primary and secondary education. Next to realizing an acceptable technology infrastructure, by means of refurbished computers from Western Europe, Teacher Education Colleges are supported to provide technology training for teacher education students (Ministry of Education and Vocational Training 2006a, b; Tilya 2008). In addition to these initiatives this study focused on the preparation of teachers who are already part of the teaching force. The study started from the perspective that to appropriately prepare teachers for the integration of technology in their teaching practice, teachers not only needed to acquire basic knowledge and skills of technology, but also needed to become competent in science and science pedagogy (cf. the ideas put forward in the TPCK framework) and student-centered education in particular. However, teaching and learning of science in Tanzania has been teacher-centered for many years (e.g. Osaki 1999, 2004; Chonjo et al. 1996). So teachers, but also students are not used to student-centered learning. A major challenge therefore was to prepare teachers in creating student-centered learning environments supported by technology.

There are numerous technology applications for science education (see for instance Webb 2008). In this study the choice was made to prepare science teachers for the integration of Microcomputer Based Laboratories (MBL) in the upper secondary physics curriculum in Tanzania. MBL is a technology application which uses data logging hardand software. MBL typically can be used in student laboratory work.

\section{The In-Service Arrangement}

Based on the theoretical underpinnings described above an in-service arrangement for upper secondary physics teachers was developed. The in-service arrangement consisted of three five-day workshops. Table 1 presents an overview of the workshop activities in relation to the TPCK framework and strategies for teacher learning.

The workshops were conducted by a teacher educator in physics, who was also researcher in this study. The workshops aimed at helping teachers to develop TPCK by an in-depth understanding of science content and MBL, as well as student-centered methods to help their students learn science content. Educative curriculum materials were a central component of the workshops. The educative curriculum materials aimed at helping teachers to understand the instructional and organizational procedures of MBL-supported student-centered lessons. The curriculum materials were based on the predict-observe-analyze sequence (Laws 1997) and contained activities focused on prediction, design of a lab experiment, data analysis, comparison of prediction and results, and reflection in order to promote student-centered education. The workshops also enabled teachers to design their own lesson 
Table 1 Relation of workshop activities with TPCK framework and strategies for teacher learning

$W s$ workshop, $T K$ technological knowledge, $T C K$ technological content knowledge, $P C K$ pedagogical content knowledge, TPCK technological pedagogical content knowledge

\begin{tabular}{|c|c|c|c|}
\hline Components of workshop activities & Ws & $\begin{array}{l}\text { TPCK } \\
\text { frame-work }\end{array}$ & Teacher learning strategies \\
\hline Introduction in basic computer skills & 1 & TK & Collaboration \\
\hline $\begin{array}{l}\text { Introduction in the use and added value } \\
\text { of MBL }\end{array}$ & 1 & TCK & Collaboration \\
\hline $\begin{array}{l}\text { Use of MBL through educative curriculum } \\
\text { materials for different science topics }\end{array}$ & All & TPCK & $\begin{array}{l}\text { Educative curriculum materials; } \\
\text { collaboration }\end{array}$ \\
\hline $\begin{array}{l}\text { Discussion of materials on practicality } \\
\text { for classroom use }\end{array}$ & All & TPCK & $\begin{array}{l}\text { Grounding learning in classroom } \\
\text { practice }\end{array}$ \\
\hline $\begin{array}{l}\text { Introduction in student-centered pedagogical } \\
\text { approaches, including student pre-conceptions }\end{array}$ & 2 & PCK & \\
\hline $\begin{array}{l}\text { Development of an MBL activity by participating } \\
\text { science teachers }\end{array}$ & 2 & TCK & Learning by design \\
\hline $\begin{array}{l}\text { Development of MBL-supported science } \\
\text { lesson materials by teachers }\end{array}$ & 3 & TPCK & Learning by design \\
\hline $\begin{array}{l}\text { Teaching of own lesson materials to colleagues } \\
\text { and researcher (micro teaching) }\end{array}$ & 3 & TPCK & $\begin{array}{l}\text { Grounding learning in classroom } \\
\text { practice }\end{array}$ \\
\hline $\begin{array}{l}\text { Revision of the developed lesson materials } \\
\text { based on feedback }\end{array}$ & 3 & TPCK & Feedback from practitioners \\
\hline
\end{tabular}

plans based on the educative lesson materials provided to them. Peer teaching some of the lesson plans developed by the teachers was part of the workshop activities.

\section{Purpose of the Study}

This study aimed at getting a better understanding of inservice arrangements conducive for teacher learning about the integration of technology (in this study MBL) in science education. According to Guskey (2000) the impact of such an arrangement for teacher learning should be visible in teachers' classroom practice and student outcomes. For this reason we used the following indicators to determine teacher learning: (1) the extent to which the science teachers were able to practice what they learned during the in-service arrangement in their classroom teaching and (2) their reflections on their classroom practice. Because for the teachers involved in the study the use of MBL in their classroom practice was new we did not think it yet appropriate to study the impact of the new classroom environment on student performance, therefore we limited ourselves to students' learning experiences. The third indicator for teacher learning then was (3) students' experiences of the classroom environment their teachers had created. Mixed methods were used for data collection.

\section{Methods}

\section{Respondents}

Four teachers, who had participated in the in-service arrangement and their students $(N=151)$ from three schools were involved in the study. The three schools could be considered representative of the variation that exists in Tanzanian secondary schools. School $\mathrm{X}$ is a large public school, school $\mathrm{Y}$ is a rich private school, and school $\mathrm{Z}$ is a private school, but from a budget perspective more comparable to a public school. The three schools involved in the study possessed basic computer facilities. School X had a computer lab with restricted access for students. School Y had a computer lab with open access for students. This school also offered computer literacy courses to their students. School $\mathrm{Z}$ also had a computer lab available for students, but the computer literacy courses in this school were not offered to upper secondary education students. The four teachers were typical science teachers with a bachelor qualification and about 6 years experience in science teaching. They were all teaching physics in upper secondary education. Teachers T1 and T2 had large classes, while the class size of the two teachers from the private schools were fairly small. Most students in the public school (school X) did not have technology literacy skills. About half of the students in school $\mathrm{Z}$ were computer literate. At the contrary all students in school $\mathrm{Y}$ were computer literate. Teachers T1, T2 and T3 spent about $10-11 \mathrm{~h}$ on the MBL-supported science lessons, while teacher T4 spent $21 \mathrm{~h}$. A summary of schools and teacher background information is provided in Table 2 .

\section{Procedure}

The three workshops were held during the spring and summer preceding lesson implementation. As part of the workshop teachers developed their own MBL-supported lessons, which they implemented in the first semester 
Table 2 Summary of background information of the schools and teachers participating in the study

\begin{tabular}{|c|c|c|c|c|c|}
\hline & \multicolumn{2}{|l|}{ School X } & \multicolumn{2}{|l|}{ School Y } & \multirow{2}{*}{$\begin{array}{l}\text { School Z } \\
\text { Teacher T4 }\end{array}$} \\
\hline & Teacher T1 & Teacher T2 & Teacher T3 & & \\
\hline Class size & 52 & 60 & 13 & 15 & 11 \\
\hline Grade level & 14 & 13 & 13 & 14 & 14 \\
\hline Age range (years) & $18-20$ & $17-19$ & $16-18$ & $17-19$ & $19-20$ \\
\hline Students computer experience & Few literate students & Few literate students & At least 5 years & At least 6 years & $1 / 2$ of class literate \\
\hline Teacher background & B.Sc. (Engineering) & B.Sc. (Education) & B.Sc. (Education) & & B.Sc. (Education) \\
\hline Teacher teaching experience (years) & 6 & 6 & 5 & & 7 \\
\hline Number of hours spent on MBL lessons & 11 & 11 & 10 & 10 & 21 \\
\hline
\end{tabular}

following the workshops. Data collection took place just before, during and just after implementation, as well as 6 months after implementation. The researcher provided the schools participating in the study with five MBL kits each.

\section{Instruments}

\section{Classroom Observation Checklist}

The classroom-observation checklist measured to what extent teachers' classroom practices reflected a studentcentered approach in the MBL-supported science lessons. A student-centered approach was considered to contain components of Learning by Inquiry, Active Learning, Collaboration and Formative Assessment. Based on these components a classroom observation checklist was developed and used as instrument for the collection of data on teachers' classroom practice. The classroom observation checklist was based on a tool developed and validated by Ottevanger (2001) in a context similar to the present study. The instrument was slightly modified for the purpose of this study. Examples of items from the classroom observation checklist are presented in Table 3. Data were collected by observing teachers teaching the MBL-supported science lessons they had developed during and after the in-service arrangement. The researcher took notes during the lesson observation. Immediately after each lesson the researcher used his notes to complete the checklist. Twenty-six lessons

Table 3 Example items from the classroom observation checklist

\begin{tabular}{llll}
\hline Items & $\begin{array}{l}\text { Yes } \\
(=1)\end{array}$ & $\begin{array}{l}\text { No } \\
(=0)\end{array}$ & Elements \\
\hline $\begin{array}{l}\text { Teacher stimulates less motivated } \\
\text { groups }\end{array}$ & $\square$ & $\square$ & Collaboration \\
$\begin{array}{l}\text { Teacher encourages learners to ask } \\
\text { questions }\end{array}$ & $\square$ & $\square$ & Active \\
$\begin{array}{l}\text { Teacher asks students to explain their } \\
\text { results }\end{array}$ & $\square$ & $\square$ & Inquiry \\
$\begin{array}{l}\text { Teacher helps students understand } \\
\text { discrepancies in their results }\end{array}$ & $\square$ & $\square$ & Formative \\
\hline
\end{tabular}

taught by the four teachers were observed. The scores on individual statements of the instrument were counted for each of the 26 observations and the counts were expressed in percentages of the maximum score for each of the three sections. Next to the checklist the researcher's notes were used to analyze the lessons.

\section{Teacher Interview}

Information about teachers' perception of the MBL-supported student-centered science lessons they had prepared and taught was collected through interviews that were conducted both immediately and 6 months after classroom implementation. The topics addressed during the interview were teaching suitability of the lessons, benefits to learning, opinions of MBL as a tool in science education, the student-centered approach to science teaching, and the fit of the lessons with the current curriculum. The interviews were audio-taped. The audio tapes were transcribed and the transcriptions were coded using pattern coding techniques (Miles and Huberman 1994).

\section{Computer Classroom Environment}

Students' perceptions of their classroom environment was determined through the computer classroom environment inventory (CCEI-Maor and Fraser 1996). The CCEI measures student attitudes towards an inquiry-oriented, technology-rich learning environment. It was administered twice (before and after classroom implementation) and consisted of 30 items along five scales: investigation (e.g. 'In these computer sessions I found the answers to questions by investigation'), open-endedness (e.g. 'In this computer class, I'm encouraged to design my own ways of solving the problems'), organization (e.g. 'I find that the computer sessions are well organized'), material environment (e.g. 'The computers are in good working conditions'), and satisfaction (e.g. 'The work with computers in this class is enjoyable'). For each scale there are six similar items. Possible responses to an item are (1) 
never, (2) seldom, (3) sometimes, (4) often, or (5) very often the case. The investigation $(\alpha=0.73)$, open-endedness $(\alpha=0.60)$, organization $(\alpha=0.67)$, material environment $(\alpha=0.64)$, and satisfaction $(\alpha=0.83)$ scales are used for this evaluation.

\section{Student Opinions on MBL-supported Lessons}

A questionnaire consisting of 15 items on student opinions of the MBL-supported science lessons was developed for the study. Possible answers to an item were on a five point Likert scale $(1=$ very helpful, $2=$ helpful, $3=$ moderately helpful, $4=$ of little help, and $5=$ not at all helpful). The questionnaire had four scales with acceptable reliability: Learning physics $(\alpha=0.74)$ (e.g. 'Activities using MBL helped me to understand more about the topic'), Lesson structure $(\alpha=0.68)$ (e.g. 'Doing prediction before the activity assisted in solving the problem'), Laboratory advantage $(\alpha=0.73)$ (e.g. 'Use of data logging hard- and software to analyze experimental data contributed to tackling the problem') and Active learning $(\alpha=0.65)$ (e.g. 'Discussing problems with a partner helped me tackle the given problem'). The questionnaire was administered immediately after classroom implementation.

\section{Results}

\section{Teachers' Classroom Practice}

The MBL-supported science lessons which the teachers had developed had a start, a body and a conclusion part. At the start of the lesson the teacher introduced the lesson topic by questioning the students about their ideas. In the body of the lesson students worked in small groups which were maintained during conclusion of the lesson. The groups discussed their predictions about the outcome of the experiment. Then they explored the experimental plan and the equipment (including the MBL kits) they were to use, took the necessary measurements and carried out some preliminary analysis of the data gathered. In the conclusion part of the lesson groups of students presented their lesson results and conclusions and teacher posed questions to promote discussion among the students.

Table 4 shows the results of the extent to which the four teachers had practiced a student-centered approach in which they utilized MBL. All teachers did relatively well in facilitating collaborative learning. The table shows that teacher T3 scored above the average on all four indicators, while teacher T2 scored below average. Teacher T2 had particularly difficulties in realizing Learning by Inquiry and Active Learning. Formative assessment was found hard by teacher T1. The scores of the teachers are not
Table 4 Average score of classroom observation of all four teachers

\begin{tabular}{lccccl}
\hline & T1 & T2 & T3 & T4 & Overall average \\
\hline Learning by inquiry & 53 & 49 & 59 & 61 & 56 \\
Active learning & 55 & 49 & 60 & 58 & 56 \\
Collaborative learning & 69 & 65 & 75 & 64 & 68 \\
Formative assessment & 52 & 56 & 57 & 56 & 55 \\
Average by teacher & 57 & 55 & 63 & 60 & 59
\end{tabular}

Scores are expressed as percentage of the maximum possible score

impressive, but given the fact that the use of MBL and the approach to teaching and learning was new for all teachers involved, the average scores could be considered acceptable.

A more detailed description of the way teachers practiced MBL-supported student-centered learning is based on a further analysis of the researcher's notes.

During the lessons the activities were carried out in groups of students (collaborative learning). The initial group formation was not complex. Students who were sitting together formed a group. In all classes the students tended to form permanent groups after working together on a few activities. Most groups seemed well organized and worked as a team. Teachers $\mathrm{T} 1$ and $\mathrm{T} 2$ created fairly big groups of about 5 students each. The groups of teachers T3 and T4 had only 2-3 students. The teachers, except for teacher T3, usually did not assign specific roles to group members.

The predict-observe-analysis (Learning by Inquiry) sequence usually was introduced at the start of each lesson, after having probed students' prior knowledge of the lesson topic. Teacher T3 always asked his students to predict the outcomes of the demonstration or the lab work. Then students explored the validity of their solution through experimentation in their groups. The inquiry process in the two classes of teacher T3 culminated with explaining the findings of the exploration. Teacher T1 guided the students through the activities and modeled a bit of what the learners were supposed to do. The teacher reminded the learners about the predict-observe-analysis sequence. Teacher T4 tried to initiate a classroom discussion where students compared their prediction with the results in the concluding part of the lessons, but his students did not feel comfortable during the discussion. Teacher $\mathrm{T} 2$ was practicing the prediction-observe-analysis sequence least. This teacher focused on the explanation of theory and difficult concepts before students started with the practical activity.

The teacher's role was to provide guidance and assistance to actively engage students (Active Learning). In the beginning the teachers were overwhelmed by requests for assistance from students, as the teaching method was new to all parties and students were not ready to take steps without their teacher's assistance. This was particularly 
true for teachers T1, T2 and T4, who needed to also instruct their students in basic computer skills necessary to conduct the lab work. As a result the teachers were very active; basically, one could say that in the beginning the teachers carried out the activities themselves. As the lessons proceeded, teacher T1 would circulate through the room, checking what the students were doing, asking questions and offering assistance. The role teacher T2 adopted was rather distant, only checking whether everything was ok, but the students seem self-motivated. Teacher T3 was going around the groups asking questions and helping those with problems in deciding the method or setting up the equipment. He was also trying to push students to keep track of time and finish on time. Also teacher T4 was going around the class during the group activities helping students in many ways. Because there was so much time, this teacher spent a lot of time with each group working closely. In some cases, he helped the students to set up the equipment and produce the first results.

Opportunities for students to promote in-depth understanding were particularly apparent during the start and conclusion of the lessons (Formative Assessment). At the start of the lesson all teachers tried to probe students' prior knowledge but not all were able to use the prior knowledge of the students properly for introducing the new activity. In the concluding part of the lesson all four teachers had difficulties in posing questions that fostered the discussion in such a way that students had time to reflect on what they had learned. Teacher T3 always started by asking questions to determine students existing knowledge, summarized the ideas and linked them to the lab-problem to be solved. The students of teacher T3 were actively participating by asking a lot of questions and providing solutions to problems. However, in the concluding part of the lesson teacher T3 often had too little time for discussing the results and did often not finalize the discussion in a proper way. Teacher T1 also started the lesson with posing questions to students. But sometimes students gave answers that were neither completely right nor completely wrong and the teacher ignored the answers and moved on to ask other students. Although teacher T1 sometimes asked the groups to explain how the results compared to their prediction, he did not discuss with the groups which approach was proper and which groups had achieved the right conclusion. To recall previous knowledge teacher T2 usually asked questions to his students at the start of the lesson. In the concluding part of the lesson teacher $\mathrm{T} 2$ was often too quick to provide answers and left little room for students to think about an answer and contribute to the discussion. Teacher T4 started with an interactive introduction, but took the lead in asking most of the questions. The problem was that his students were not used to asking good questions, therefore the questioning was more in one direction. In the concluding part of the lessons teacher T4 devoted more time to the discussion than the other teachers, but as the students were not asking many questions, the discussion was dull. The conclusions were mostly teacher driven and not always clearly explained to the students.

\section{Teachers' Reflection}

During the reflective interview, the four teachers had opportunities to clarify their opinion about the MBL-supported student-centered lessons. Teachers $\mathrm{T} 1$ and $\mathrm{T} 2$ jointly agreed that the MBL-supported lessons were well executed. They believed if they were to redo the same lessons, they could use what they had learned from the first experience to achieve more with the same resources. The teachers believed that most students had a positive view about the possibilities of MBL for learning physics, especially because it produced accurate measurement and assisted in analyzing results, while also saving time. Certainly because of the different lesson structure and the MBL software, students had some difficulties in making the transition from the teaching they were used to. Teacher T1 affirms that the lesson structure made students think, and that thinking on the part of students was necessary to complete the lessons. Teacher $\mathrm{T} 1$ also had noticed that a few students were not so engaged because, according to the teacher, "Those students thought MBL was not going to feature in exams, so why bother." Teacher T2's position was that MBL and traditional lesson plans achieve the same thing, only that MBL is more efficient and good in data analysis. Reacting to the question what he thought about the student-centered approach teacher T2's opinion was that "If you investigate a new concept then you can start with a lab, but as we do nothing new in physics we better teach students the theoretical part, and then verify by lab work." Teacher T3 had experienced that his students liked making predictions and carrying out challenging exercises. His comments were, "A student exposed to that, will be privileged because (s)he is geared towards making a good scientist'. He also emphasized the importance of context-rich exercises. Responding to a question on how his practice differs from his previous practice, he explained, "Earlier I will just go to class give students the experiment as it was in the text but, but now I redesign the experiment such that students will learn in a more productive way. I include prediction as part of experiment. Also when I teach I am concerned about the misconceptions students have before I teach a new topic." The teacher felt students were highly motivated as asserted this by the following: "Majority of students liked the lessons. I have never seen something else moved my students the same way in physics. They don't like physics very much but the activities were different." The teacher revealed, 
"Students who before were not active in class, were very active in doing MBL activities... so physics learning was very good." To him the MBL activities had benefits related to laboratory studies such as quick data analysis, and cognition such as development of concepts. Teacher T4 perceived the implementation of the student-centered environment as a success for a number of reasons. The students liked the way the lessons were designed and they received enough support during the lessons. Additionally, through the group work students were able to exchange ideas that made learning easier for them. Teacher T4 also thought the students greatly enjoyed MBL, but he was slightly reserved and cautious in making claims about its effectiveness, partly because the amount of experience using MBL in school was relatively short compared to the traditional approach. Using the computer for doing science was also a new experience for most students as many students were only familiar with using the computer for word processing. Students could do more in the time allocated for lab work and probably learn more. A final measure of success for MBT according to teacher T4 was that the lessons support group learning, which he saw as the best way for helping them to cooperate, learn and understand from each other.

\section{Students' Perceptions of Their Learning Environment}

Pre- and post-test data on the CCEI showed a significant change of student perception of their classroom environment for investigation $(t=2.87, d f=122, p<0.05)$, open-endedness $(t=3.22, d f=122, p<0.05)$ and material environment $(t=8.29, d f=122, p<0.05)$. Overall, the results showed that students were satisfied with the learning environment. They experienced that their learning environment had become more investigative and openended, and they found the computer hardware and software adequate and user friendly. These results suggest that in the MBL-supported lessons a supportive learning environment was created that fostered a student-centered approach to science education.

Figure 1 shows per teacher how the students perceive the learning environment at the end of the MBL-supported science lessons. As Fig. 1 illustrates, students of teacher T4 from the $Z$ school consistently displayed a more positive perception towards the classroom environment than their peers of the other teachers - a trend consistent across all five sub-scales of the CCEI. A Kruskal-Wallis test was performed to determine to what extent the differences between the students of the four teachers were significant on the scales of the CCEI. Significant differences were found on perceptions related to open-endedness $\left(\chi^{2}=11.29\right.$, $d f=3, p<0.05)$ and satisfaction $\left(\chi^{2}=21.20, d f=3\right.$, $p<0.05)$. The more positive perception of teacher $\mathrm{T} 4$

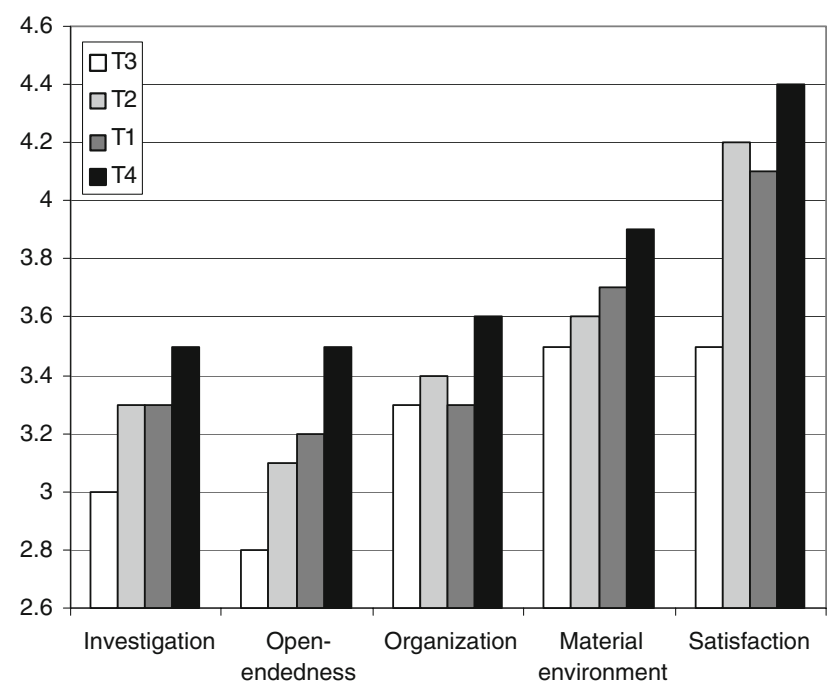

Fig. 1 Students' perceptions of the learning environment at the end of the MBL-supported lessons, per teacher ( $N=126$ in total)

could be due to the fact that these students have spent more time on the MBL-supported lessons. It is interesting to note that students of teacher T3 from the $Y$ school have less favorable perceptions compared to the students of the other teachers. This is surprising because teacher T3 scored higher in practicing MBL-based student-centered science education (see also Table 5). One of the reasons to explain this could be that the students' previous experience with computers had shaped their perceptions on how computers can be used for educational purposes. May be the time the students of teacher T3 spent with the new MBL-supported application was not long enough to change these preconceived notions. In addition also the notion of teacher T3 that his students do not like physics and that the physics lessons (also the MBL-based lessons) could become more interesting when they were more linked to daily-life experiences might be an explanation.

Overall students' opinions about the MBL-supported lessons were positive. Students' hold the opinion that the MBL-supported lessons were good for learning physics concepts and principles (59\% answered (very) helpful), were well-structured (67\%-(very) helpful), and supported active learning (72\%-(very) helpful), and because with MBL, the labs had the advantage of a better data collection and analysis process over traditional lab activities (69\%-(very) helpful). However, the story is different when a comparison is made between students of teachers from the different schools. The comparative results are presented in Table 5.

Significant differences between students' opinions of the four teachers were found to the extent to which MBLsupported lessons were helpful in learning physics $\left(\chi^{2}=15.11, d f=3, p<0.05\right)$, had advantage for laboratory work $\left(\chi^{2}=14.49, d f=3, p<0.05\right)$ and for lesson structure $\left(\chi^{2}=8.39, d f=3, p<0.05\right)$. In line with the 
Table 5 Students' score on four sub-scales by teachers

\begin{tabular}{|c|c|c|c|c|c|c|c|c|c|c|}
\hline \multirow{3}{*}{$\begin{array}{l}\text { Schools } \\
\text { Teachers }\end{array}$} & \multicolumn{4}{|l|}{$\mathrm{X}$} & \multirow{2}{*}{\multicolumn{2}{|c|}{$\frac{\mathrm{Y}}{\mathrm{T} 3(N=27)}$}} & \multirow{2}{*}{\multicolumn{2}{|c|}{$\frac{\mathrm{Z}}{\mathrm{T} 4(N=11)}$}} & \multirow[t]{3}{*}{$\chi^{2}$} & \multirow[t]{3}{*}{ Sig* } \\
\hline & \multicolumn{2}{|c|}{$\mathrm{T} 1(N=28)$} & \multicolumn{2}{|c|}{$\mathrm{T} 2(N=60)$} & & & & & & \\
\hline & Mean & SD & Mean & $\mathrm{SD}$ & Mean & SD & Mean & SD & & \\
\hline Learning & 1.9 & 0.7 & 2.0 & 0.9 & 2.5 & 0.8 & 1.7 & 0.3 & 15.11 & $0.002 *$ \\
\hline Lab advan. & 1.7 & 0.8 & 1.8 & 0.8 & 2.5 & 0.9 & 1.6 & 0.7 & 14.49 & $0.002 *$ \\
\hline Lesson structure & 1.9 & 0.7 & 2.3 & 1.1 & 2.6 & 0.9 & 2.6 & 1.0 & 8.35 & $0.039 *$ \\
\hline Active learning & 2.3 & 1.0 & 2.1 & 0.9 & 2.0 & 0.8 & 2.2 & 0.9 & 1.24 & 0.739 \\
\hline
\end{tabular}

Scores range from 1 (very helpful) to 5 (not helpful at all)

* Statistically significant $(p<0.05)$

findings from the CCEI the students from teacher T3 expressed a less positive opinion about the lessons compared to the other students. In particular they leaned towards the opinion that the MBL-supported lessons were only moderately helpful for learning physics and in the laboratory. The students of teacher T4 on the contrary displayed a more positive opinion towards the lessons than students from the other teachers; they regarded MBL as being good for lab work and learning physics. Compared to their fellow students, the students of teacher T1 were more positive about structure of the lessons and the students from teacher T3 were slightly most positive about the MBL-supported lesson for active learning, although the latter was not statistically significant.

\section{Discussion}

This study started with the assumption that teachers needed to learn how to adequately integrate technology, in this study MBL, in their educational practice. By using the ideas of the Technological Pedagogical Content Knowledge Framework (Mishra and Koehler 2006; Koehler and Mishra 2008) and ideas about teacher learning (Borko and Putnam 1996; Elmore and Burney 1999) an in-service arrangement for upper secondary physics teachers in Tanzania was developed in which educative lesson materials were a main component. In this study we investigated to what extent teachers were able to practice what was learned during the in-service arrangement using the following indicators: (1) teacher's ability to conduct MBL-supported student-centered science lessons; (2) teacher's reflection on their classroom practice and (3) students' perceptions of the classroom environment the teachers had created.

Given the fact that both MBL and student-centered science education were new to the teachers in the study, the four teachers demonstrated an acceptable level of implementation of the MBL-supported student-centered science lessons. The teachers found it relatively easy to organize group work (Collaboration), but they experienced Learning by Inquiry, Active Learning and Formative Assessment as more difficult. Three of the four teachers found it difficult to make use of students' prior knowledge and to encourage classroom discussions about predictions and findings, which illustrates that science pedagogy (Pedagogical Content Knowledge) in the TPCK framework was considered difficult. Because students' were not familiar with the technology teachers had to put a lot of effort in guiding the students during practical work, they seemed to be prepared for that (Technological Content Knowledge in terms of the TPCK framework), but had problems in managing the classroom. Hence, teachers were not yet able to perfectly blend the components of TPCK. The findings illuminate that it teachers needed time to practice a new approach to science teaching. Over the years, in the context of the classroom, teachers have constructed their own "personal practical knowledge" - "an integrated set of knowledge, conceptions, belief, and values"-which greatly influences their practices and how they respond to educational change (van Driel Beijaard and Verloop 2001, p. 141). All teachers found the use of MBL in science education particularly useful for acquiring good measurements and for its support in the process of data analysis. They experienced that MBL also saved curriculum time; a benefit of MBL, which is also mentioned by other researchers (Redish et al. 1997; Voogt 1996). Three of the four teachers had experienced that a student-centered approach to science teaching helps students to better learn science. But they mentioned that for a successful implementation alignment of MBL-supported student-centered science teaching with the curriculum and current assessment practices is necessary.

Given the fact that the use of MBL for students was new it was not very surprising that the students appreciated the MBL-based lessons and valued their classroom environment as more investigative and more open-ended compared to their usual science lessons. It was surprising that the students from the teacher, who had implemented the student-centered approach best, seemed somewhat more critical to the new approach than the students from the other teachers. May be because the student-centered 
approach was better implemented the students of this teacher experienced the new approach as more demanding than their peers. If this assumption holds than more attention is needed to guide students, and not only teachers, in coping with new pedagogical approaches.

Law et al. (2008) in the international study on technology integration in education have found strong correlations between teachers adoption of technology and pedagogically (instead of technically oriented) in-service arrangements for technology integration. By focusing on the TPCK framework and using strategies for professional development that have proven to be effective we have tried to design an intervention that complied with these findings. In terms of stages of adoption of (technology) innovations (Sandholtz et al. 1997; Christensen and Knezek 2008) the teachers were unaware of the possibilities of technology for science education before they participated in the in-service arrangement, but had moved to the stage of 'Understanding and application of the process' (Christensen and Knezek) or 'Adaptation' (Sandholtz et al.), as became clear during lesson observations and through student perceptions of the classroom environment the teachers had created. Based on the indicators for teacher learning that were used in this study, we can conclude that the in-service arrangement had impacted teacher's ability to plan and conduct MBL-supported student-centered science lessons, but that it certainly was not yet part of their routines. A number of factors accounted for the impact of the in-service scenario. The workshops made it possible to reflect and discuss with colleagues the use of MBL and a student-centered approach to science education. The educative lesson materials helped teachers to understand the practical meaning of student-centered science education and offered concrete applications of MBL as a means in the teaching and learning process. A safe environment for teachers was created in which they could peer-teaching own developed lessons. In this way strong links could be made to personal learning and the classroom context, which is important for changing teacher beliefs and practices (Davis 2003).

Acknowledgments The authors wish to thank Jules Pieters for reviewing an earlier version of this article.

Open Access This article is distributed under the terms of the Creative Commons Attribution Noncommercial License which permits any noncommercial use, distribution, and reproduction in any medium, provided the original author(s) and source are credited.

\section{References}

Ball D, Cohen D (1996) Reform by the book: what is - or might bethe role of curriculum materials in teacher learning and instructional reform? Educ Res 25(9):6-14
Black P, Wiliam D (1998) Assessment and classroom learning. Assess Educ Princ Policy Pract 5(1):7-74

Borghi L, Ambrosis A, Mascheretti P (2003) Developing relevant teaching strategies during in-service training. Phys Educ 38(1):41-46. doi:10.1088/0031-9120/38/1/307

Borko H, Putnam RT (1996) Learning to teach. In: Berliner DC, Calfree RC (eds) Handbook of educational psychology. Macmillan, New York, pp 673-708

Bransford JD, Brown AL, Cocking RR (eds) (2000) How people learn. Brain, mind, experience, and school. Expanded edition. National Academy Press, Washington

Chonjo PN, Osaki KM, Possi M, Mrutu S (1996) Improving science education in secondary schools: a situational analysis of selected government secondary schools in mainland Tanzania. Report of study sponsored by GTZ and MOEC, Dar es Salaam

Christensen R, Knezek G (2008) International handbook of information technology in primary and secondary education. Springer, New York, pp 349-365

Davis KS (2003) Change is hard: what science teachers are telling us about reform and teacher learning of innovative practices. Sci Educ 87(1):3-30. doi:10.1002/sce.10037

Davis EA, Krajcik JS (2005) Designing educative curriculum materials to promote teacher learning. Educ Res 34(3):3-14

Dede C (2000) Emerging influences of information technology on school curriculum. J Curric Stud 32(2):281-303. doi:10.1080/ 002202700182763

Dillenbourg P (1999) Introduction: what do you mean by collaborative learning? In: Dillenbourg $\mathrm{P}$ (ed) Collaborative learning: cognitive and computational approaches. Pergamon, Oxford, pp 1-19

Elmore RF, Burney D (1999) Investing in teacher learning. In: Darling-Hammond L, Sykes G (eds) Teaching as the learning profession. Jossey-Bass, San Francisco, pp 236-291

Guskey TR (2000) Evaluating professional development. Corwin Press, Thousand Oaks

Koehler MJ, Mishra P (2008) Introducing TPCK. In: AACTE committee on innovation and technology (ed) Handbook of technological pedagogical content knowledge (TPCK) for educators. Routledge, New York/London, pp 3-29

Law N, Pelgrum WJ, Plomp T (eds) (2008) Pedagogy and ICT in schools around the world: findings from the SITES 2006 study. CERC Springer, Hong Kong

Laws P (1997) Millikan lecture 1996: promoting active learning based on physics education research in introductory physics courses. Am J Phys 65:14-21. doi:10.1119/1.18496

Lumpe AT, Oliver JS (1991) Dimensions of hands-on science. Am Biol Teach 53(6):345-348

Maor D, Fraser BJ (1996) Use of classroom environment perceptions in evaluating inquiry-based computer assisted learning. Int J Sci Educ 18(4):401-422. doi:10.1080/0950069960180402

McCrory R (2008) Science, technology, and teaching: the topic specific challenges of TPCK in science. In: AACTE committee on innovation and technology (ed) Handbook of technological pedagogical content knowledge (TPCK) for educators. Routledge, New York, pp 193-206

Miles MB, Huberman AM (1994) Qualitative data analysis. Sage, London

Ministry of Education and Vocational Training (2006a) Programme for ICT in secondary schools in Tanzania. Ministry of Education and Vocational Training, Dar es Salaam

Ministry of Education and Vocational Training (2006b) Towards an ICT policy: a strategy for secondary education in Tanzania. Ministry of Education and Vocational Training, Dar es Salaam

Mishra P, Koehler M (2006) Technological pedagogical content knowledge: a framework for teacher knowledge. Teach Coll Rec 108:1017-1054. doi:10.1111/j.1467-9620.2006.00684.x 
Osaki KM (1999) Science education in secondary schools (SESS): an internal project evaluation, commissioned by GTZ. Ministry of Education and Culture \& GTZ, Dar es Salaam

Osaki K (2004) Reflections on the state of science education in Tanzania. In: Osaki K, Hosea K, Ottevanger W (eds) Reforming science and mathematics education in sub-Saharan Africa. University of Dar es Salaam, TEAMS project, Dar es Salaam, pp 11-26

Ottevanger W (2001) Teacher support materials as a catalyst for science curriculum implementation in Namibia. Doctoral dissertation, University of Twente, Enschede

Redish E, Saul J, Steinberg R (1997) On the effectiveness of activeengagement microcomputer-based laboratories. Am J Phys 65(1):45-54. doi:10.1119/1.18498

Sandholtz J, Ringstaff C, Dwyer DC (1997) Teaching with technology: creating student-centered classrooms. Teachers College Press, New York

Tilya F (2008) IT and educational policy in the sub-Saharan African region. In: Voogt J, Knezek G (eds) International handbook of information technology in primary and secondary education. Springer, New York, pp 1145-1154
Van den Akker J (1988) The teacher as learner in curriculum implementation. J Curric Stud 20(1):47-55. doi:10.1080/002 2027880200104

Van Driel JH, Beijaard D, Verloop N (2001) Professional development and reform in science education: the role of teachers' practical knowledge. J Res Sci Teach 38(2):137-158. doi:10.1002/ 1098-2736(200102)38:2<137::AID-TEA1001>3.0.CO;2-U

Voogt JM (1996) Microcomputer-based laboratories in inquiry-based science education - an implementation perspective. In: Tinker RF (ed) Microcomputer-based labs: educational research and standards. Springer, Berlin, pp 207-223

Voogt J (2003) Consequences of ICT for aims, contents, processes and environments of learning. In: van den Akker J, Kuiper W, Hameyer U (eds) Curriculum landscapes and trends. Kluwer, Dordrecht, pp 217-236

Webb M (2008) Impact of IT on science education. In: Voogt J, Knezek G (eds) International handbook of information technology in primary and secondary education. Springer, New York, pp $133-148$ 